\title{
Effect of EDTA on the resistance of clinical isolates of Acinetobacter baumannii to the bactericidal activity of normal human serum
}

\author{
APOLINARIA GARCÍA, HENRY SOLAR, CARLOS GONZÁLEZ and RAÚL ZEMELMAN \\ Departamento de Microbiología, Facultad de Ciencias Biológicas, Universidad de Concepción, Casilla 160-C, \\ Concepción, Chile
}

\begin{abstract}
Acinetobacter baumannii is an opportunist nosocomial pathogen of world-wide importance and produces severe infections in immunocompromised patients. However, the virulence factors contributing to its pathogenic properties are not well known. The effect of normal human serum against 18 clinical isolates of the most prevalent biotypes of $A$. baumannii in Chile was investigated. The effect of pre-treatment of the cells with ethylene diamine tetraacetic acid (EDTA) or bismuth subsalicylate (BSS), compounds known to decrease the amount of lipopolysaccharide (LPS) and bacterial capsular polysaccharide (CPS), respectively, in other gram-negative bacteria, was evaluated. Most isolates (16 of 18) showed resistance to normal human serum. Prior treatment with EDTA rendered nine of these isolates susceptible to serum, while seven isolates maintained their resistance. Pre-treatment with BSS did not modify the serum-resistant behaviour of the isolates. The results suggest that LPS might be involved in the resistance of $A$. baumannii to human serum whereas CPS does not seem to contribute to this property.
\end{abstract}

\section{Introduction}

In Chile, isolates of Acinetobacter baumannii, mainly of biotype 9, exhibit wide antibiotic resistance patterns and produce diverse nosocomial infections, especially among patients in intensive care units. In other countries, different biotypes prevail in hospitals [1,2]. Prevalence of certain biotypes suggests that those micro-organisms have special properties or factors. Work in this laboratory has demonstrated that nosocomial isolates of $A$. baumannii produce a smooth-type LPS (S-LPS), and this macromolecule might contribute to pathogenicity [3]. Furthermore, many strains of Acinetobacter are capsulate and the capsular polysaccharide (CPS) might be associated with protection of bacteria from phagocytosis and complement [2].

Gram-negative organisms that give rise to bacteraemia are more resistant to normal human serum and

Received 24 Nov. 1999; revised version accepted 20 March 2000.

Corresponding author: Dr A. García (e-mail: apgarcia@, udec.cl). phagocytosis than bacteria causing other types of infections [4,5]. A significant correlation between the degree of resistance of gram-negative bacteria isolated from septicaemia to the lytic activity of complement in vitro and their ability to invade and survive in human fluids has been reported [4]. The participation of some bacterial components, such as outer-membrane or surface proteins, CPS and LPS, in this property has been demonstrated [4,5] but little is known about host defence mechanisms against Acinetobacter spp. [2]. Preliminary results reported by Traub et al. [6] revealed that treatment of clinical isolates of $A$. baumannii and Acinetobacter genospecies 3 with defibrinated human blood, with and without specific antibodies, failed to completely kill 22 strains of these organisms.

As the mechanisms of serum resistance of $A$. baumannii are incompletely understood, the aim of the present study was to evaluate the influence of pretreatment of the cells with EDTA or BSS on this property by using clinical isolates of different biotypes. These reagents are known to diminish the LPS and CPS content, respectively, in several gram-negative bacteria, including the non-fermentative species Pseudomonas aeruginosa $[7,8]$. 


\section{Materials and methods}

\section{Human serum}

Sera were obtained from 10 clinically healthy individuals who had not received any antibacterial treatment in the previous 30 days. Blood samples were incubated at $37^{\circ} \mathrm{C}$ for $1 \mathrm{~h}$ and then at $4^{\circ} \mathrm{C}$ for a further hour. Sera were removed aseptically, pooled and held at $-70^{\circ} \mathrm{C}$ until required. The pooled serum was used within 3 months of collection and its complement activity was evaluated by haemolysis before use.

\section{Micro-organisms}

Eighteen isolates from bacteraemic patients in different Chilean hospitals were included in the study. One strain of a serum-sensitive Escherichia coli (E. coli Garret, kindly provided by Dr Felipe Cabello, Valhalla, New York, USA) was used as susceptible control. Isolates of $A$. baumannii were identified and biotyped by standard microbiological methods.

\section{Serum bactericidal activity}

Bacterial cultures (100- $\mu 1$ volumes) grown in Trypticase Soy Broth (Life Technologies, Gaithersburg, MD, USA) at $37^{\circ} \mathrm{C}$, and containing c. $1 \times 10^{8} \mathrm{cfu} / \mathrm{ml}$ $\left(\mathrm{OD}_{540}\right.$ 0.17), were each mixed with $900-\mu 1$ volumes of serum, in duplicate. Immediately, $100 \mu \mathrm{l}$ were removed from each tube to determine the initial bacterial viable counts $\left(\mathrm{t}_{0}\right)$ and the mixtures were incubated at $37^{\circ} \mathrm{C}$ for $24 \mathrm{~h}$. Further $100-\mu \mathrm{l}$ volumes were removed at 2, 3 and $24 \mathrm{~h}$. For viable counting, the samples were diluted with $1 \mathrm{ml}$ of saline and collected on a membrane filter (Millipore) of $0.22 \mu \mathrm{m}$ diameter pore size. The filters were placed on the surface of Müeller-Hinton agar plates (Life Technologies) and incubated as above. Bacterial death was considered to have been achieved when surviving cells represented $\leqslant 0.1 \%$ of the initial inoculum [9]. The bacterial suspension was also assayed with heat-inactivated serum $\left(56^{\circ} \mathrm{C}\right.$ for $\left.30 \mathrm{~min}\right)$.

\section{Pre-treatment with EDTA and BSS}

To examine the effect of EDTA and BSS on the serum resistance phenotype of $A$. baumannii, the cultures were grown in trypticase soy broth supplemented with either $10 \mathrm{~mm}$ EDTA (Sigma) or $2.0 \mathrm{~mm}$ BSS (Proctor \& Gamble, Cincinatti, OH, USA), respectively, until reaching the inoculum used in the serum resistance assay $\left(\mathrm{OD}_{540}\right.$ 0.17). These concentrations of EDTA and BSS had been shown in previous assays to be subinhibitory for the isolates.

\section{Results}

The bactericidal effect of pooled normal human serum $(90 \% \mathrm{v} / \mathrm{v})$ on 18 strains of $A$. baumannii after incubation for $3 \mathrm{~h}$ is shown in Table 1 . At $1 \mathrm{~h}$, only one of the strains (A. baumannii ACA-33, biotype 9) showed any killing by the serum (data not shown). Sixteen $(88.9 \%)$ of these strains maintained their serum resistance even after they had been exposed to the pooled serum for $3 \mathrm{~h}$, and only one other strain (strain 93-70, biotype 1) was killed by this time. Similar results were obtained $24 \mathrm{~h}$ after challenge and some growth of the resistant strains was evident during the experiment. However, when pooled normal human sera was used at $30 \% \mathrm{v} / \mathrm{v}$ in the assays, none of the strains showed killing after $3 \mathrm{~h}$ (data not shown). The control strain, E. coli Garret (O1), was serum-sensitive when either $90 \%$ or $30 \%$ serum was used. This strain of $E$. coli was killed ( $<0.1 \%$ survivors) in $<15 \mathrm{~min}$, whereas the serum-sensitive strain of $A$. baumannii (ACA-33) was found to be resistant for $>30 \mathrm{~min}$, but not at $1 \mathrm{~h}$ after exposure to serum (data not shown). When heatinactivated $\left(56^{\circ} \mathrm{C}\right.$ for $\left.30 \mathrm{~min}\right)$ serum was used instead of normal human serum, no loss of viability was observed among the strains of $A$. baumannii or with the control strain, suggesting that the antibacterial activity observed was due to complement activity.

EDTA and BSS were used to assess whether LPS or CPS participate in the serum resistance of $A$. baumannii, as these reagents are known to reduce significantly the content of LPS and CPS, respectively, in several gram-negative bacteria [7,8]. Pre-treatment of the strains with EDTA rendered nine isolates (HJJA1, HS-10, HS-34 and ACA-34 of biotype 9; HJJA-25, HS-4 and HS-13 of biotype 8; HJJA-14 of biotype 17; and 95-52 of biotype 1) susceptible to serum killing, suggesting the participation of LPS in the serum resistance in $A$. baumannii (Table 1). The remaining seven strains retained their serum-resistant phenotype after EDTA treatment, probably because of the presence of different structures that may influence this property. Pre-treatment with BSS did not modify the response of any of the isolates to serum.

\section{Discussion}

Resistance to the bactericidal activity of serum is an important factor in bacterial virulence [4]. Results obtained in this study demonstrate that most clinical isolates of A. baumannii exhibit intrinsic resistance to normal human serum and that few susceptible strains are isolated. The fact that EDTA rendered isolates susceptible to serum killing suggests that LPS is involved in the resistance in some way, as shown with other gram-negative bacteria [4,7]. For example, a serum-resistant isolate of $E$. coli became serumsensitive after incubation in $10 \mathrm{mM}$ EDTA, a procedure known to release LPS [7], and this treatment resulted in enhanced and stable binding of C5b-9 to the organism. The $\mathrm{O}$ side chains of LPS are known to play an important role in the virulence of $P$. aeruginosa by conferring resistance to the bactericidal effect of 
Table 1. Bactericidal activity of pooled normal human sera on isolates of $A$. baumannii

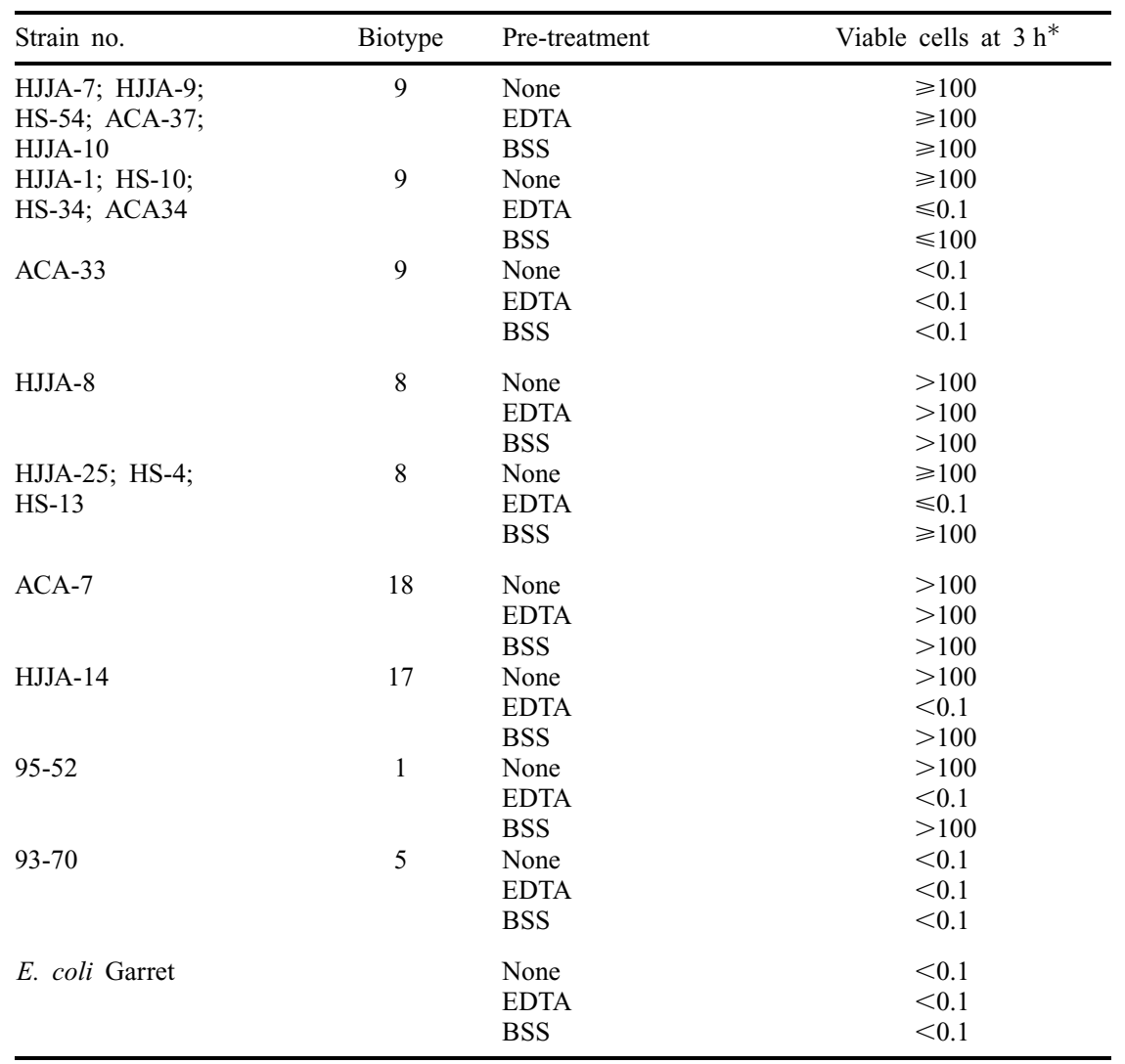

${ }^{*}$ Calculated as a percentage of the viable cell number at $t_{0}$, immediately after mixing the bacteria with the serum.

complement [10]. The $\mathrm{O}$ groups endow the long polysaccharide chain with strong hydrophilicity, an important property in both evading phagocytosis and resisting the activity of complement.

Jankowski et al. [11] found that $12 \%$ of clinical isolates of $A$. calcoaceticus var. anitratus (now $A$. baumannii) and $84 \%$ of $A$. lwoffii were susceptible to the complement-mediated (alternatively or classically activated) bactericidal activity of human serum. The authors employed an inoculum of $10^{5} \mathrm{cfu} / \mathrm{ml}$ and categorised as susceptible those strains showing $>50 \%$ killing in $3 \mathrm{~h}$. In the present investigation, inocula of $10^{7} \mathrm{cfu} / \mathrm{ml}$ were used, the incubation period was extended to $24 \mathrm{~h}$ and the criterion for killing was stricter. Nonetheless, the results were similar in that $11.1 \%$ of the A. baumannii strains were susceptible to human serum.

It is difficult to compare the results of the present study with those obtained by Traub et al. [6], as these authors used defibrinated blood. It is known that, under these conditions, several antibacterial mechanisms, such as the complement lytic system, antibodies, phagocytes and associated low mol. wt antibacterial peptides (like defensins) and also iron deprivation might be operative.

It is known that the treatment of mucoid gram-negative bacteria with BSS removes between 50 and $>90 \%$ of the CPS, depending on the bacterial species [8]. This treatment has been used successfully in $A$. baumannii and $P$. aeruginosa for isolating plasmids. Thus, the lack of effect of BSS on the serum resistance of $A$. baumannii suggests that CPS does not participate in this property, as has been demonstrated for other bacteria [5]. The effect of other bacterial components, such as outer-membrane proteins, in the resistance to serum killing cannot be ruled out.

The results of the present study suggest that the LPS of A. baumannii strains isolated from bacteraemic patients might be important in allowing the strains to survive in the blood and contributing to the pathogenesis of this species.

We thank Mrs María E. Larenas for her critical review of the manuscript.

\section{References}

1. Bello H, González G, Domínguez M, Zemelman R, García A, Mella S. Activity of selected $\beta$-lactam, ciprofloxacin, and amikacin against different Acinetobacter baumannii biotypes from Chilean hospitals. Diagn Microbiol Infect Dis 1997; 28: $183-186$.

2. Towner KJ, Bergogne-Bérézin E, Fewson CA (eds). The Biology of Acinetobacter. Taxonomy, clinical importance, 
molecular biology, physiology, industrial relevance. New York, Plenum Press. 1991.

3. García A, Salgado F, Solar H, González C, Zemelman R, Oñate A. Some immunological properties of lipopolysaccharide from Acinetobacter baumannii. J Med Microbiol 1999; 48: 479-483.

4. Valvano MA. Pathogenicity and molecular genetics of Ospecific side-chain lipopolysaccharides of Escherichia coli. Can J Microbiol 1992; 38: 711-719.

5. Russo TA, Moffitt MC, Hammer CH, Frank MM. TnphoAmediated disruption of K54 capsular polysaccharide genes in Escherichia coli confers serum sensitivity. Infect Immun 1993; 61: $3578-3582$.

6. Traub WH, Leonhard B, Bauer D. Exposure of clinical isolates of Acinetobacter baumannii and Genospecies 3 to defibrinated human blood with and without added human 'natural' or (patient) immune antibodies. Chemotherapy 1995; 41: 82-91.
7. Leive L. The barrier function of Gram-negative envelope. Ann NY Acad Sci 1974; 235: 109-127.

8. Domenico P, Landolphi DR, Cunha BA. Reduction of capsular polysaccharide and potentiation of aminoglycoside inhibition in Gram-negative bacteria by bismuth subsalicylate. J Antimicrob Chemother 1991; 28: 801-810.

9. Pearson RD, Steigbigel RT, Davis HT, Chapman SW. Method for reliable determination of minimal lethal antibiotic concentrations. Antimicrob Agents Chemother 1980; 18: 699-708.

10. Cryz SJ, Pitt TL, Fürer E, Germanier R. Role of lipopolysaccharide in virulence of Pseudomonas aeruginosa. Infect Immun 1984; 44: 508-513.

11. Jankowski S, Grzybek-Hryncewicz K, Fleischer M, Walczuk M. Susceptibility of isolates of Acinetobacter anitratus and Acinetobacter lwoffii to the bactericidal activity of normal human serum. FEMS Microbiol Immunol 1992; 89: $225-260$. 